\title{
Responses of Adrenal Corticosteroid Secretion to Hypotension and Hypovolemia *
}

\author{
Donald S. Gann $\dagger$ and Richard H. Egdahl $\ddagger$ \\ (From the Department of Surgery, Medical College of Virginia, Richmond, Va.)
}

Sayers, Sayers, Liang, and Long demonstrated that hemorrhage leads to depletion of adrenal ascorbic acid through a mechanism dependent on the pituitary and presumably involving the release of ACTH (1). Hume and Nelson presented evidence that hemorrhage was effective in increasing secretion of 17 -hydroxycorticosteroids (17-OHCS) and that this effect was dependent upon the pituitary (2). Subsequent reports have confirmed (3-5) or failed to confirm $(6,7)$ these observations without, however, extending our understanding of the mechanism by which hemorrhage stimulates release of ACTH and secretion of 17-OHCS. The present experiments represent a first attempt to define these mechanisms.

\section{Methods}

Eighty-two experiments were performed in 49 adult mongrel dogs weighing from 12 to $20 \mathrm{~kg}$ anesthetized with pentobarbital, $30 \mathrm{mg}$ per $\mathrm{kg}$. On the day before the experiment each animal's right lumboadrenal vein was cannulated by the method of Hume and Nelson (2). Thirteen dogs were nephrectomized bilaterally at the same time. In 11 animals, silk or cotton ligatures were passed about the carotid arteries low in the neck and then passed through double-lumen plastic cannulas to form chokers, as described previously (8); in four of these dogs, both vertebral arteries were ligated at this time. In 15 animals, inflatable cuffs were passed about the thoracic descending aorta; five of these animals were nephrectomized. All chokers and cuffs were brought out through closed incisions, so that constriction of the isolated vessel could be accomplished subsequently without further surgical manipulation. After all dogs had been anesthetized on the day of the experiment, they underwent cannulation of a femoral vein and one or

* Submitted for publication June 24, 1964; accepted September 4, 1964.

Supported in part by grants AM 07415 and AM 06372 from the National Institutes of Health.

$\dagger$ Special fellow, National Heart Institute (HE 19542). Present address: Western Reserve University, Cleveland, Ohio.

$¥$ Present address : Boston University School of Medicine, Boston, Mass. both femoral arteries. In addition, lingual arterial cannulas were inserted in all dogs used for carotid or aortic constriction. Arterial pressure was monitored continuously by a cannula and a Sanborn transducer and recorder. Anesthesia was maintained carefully for the next 2 hours. Animals were left undisturbed during this time to permit secretion rates of $17-\mathrm{OHCS}$ to return to basal levels.

Timed samples of adrenal venous blood were collected during control periods and at various times after introduction of a hemodynamic stimulus. Samples were analyzed by the method of Peterson, Karrer, and Guerra (9), and secretion rates were calculated as the product of blood flow and steroid concentration. All animals reported had low resting secretion rates of $17-\mathrm{OHCS}$ that rose to values in excess of $8 \mu \mathrm{g}$ per minute after injection of $100 \mathrm{mU}$ of ACTH at the end of the experiments. Each value for secretion rate of $17-\mathrm{OHCS}$ obtained after a stimulus was compared with its own control for analysis. Most dogs were used for more than one experiment. The time allowed for recovery between experiments ranged from 1 to 24 hours. Such experiments are reported only if control secretion rates of 17-OHCS were low (less than $8 \mu \mathrm{g}$ per minute). When a dog was used on more than 1 day, sensitivity to ACTH was demonstrated on each day.

In six dogs (four intact and two nephrectomized), blood was removed within 10 minutes through a femoral arterial catheter until mean arterial pressure stabilized at $60 \mathrm{~mm} \mathrm{Hg}$; the volumes of blood removed ranged from 300 to $500 \mathrm{ml}$. Samples were obtained at 15-minute intervals in these and other experiments except as noted. In five of these animals, the shed blood was reinfused within 10 minutes, beginning 1 hour after hemorrhage. In these dogs and three others (total, four intact and four nephrectomized), hemorrhage of the same order of magnitude was carried out, but hypotension was prevented by simultaneous infusion of $l$-norepinephrine (Levophed).1 Pulse pressure was well maintained, as was mean arterial pressure. Shed blood was reinfused as before in two experiments.

In 19 experiments in 17 dogs (13 intact, four nephrectomized), trimethaphan camphorsulfonate (Arfonad) ${ }^{2}$ was infused at a rate sufficient to reduce and maintain mean arterial pressure at $60 \mathrm{~mm} \mathrm{Hg}$. In five experiments in four of these dogs, Arfonad was infused at approximately the same rate, but hypotension was prevented

\footnotetext{
1 Winthrop Laboratories, New York, N. Y.
}

2 Roche Laboratories, Nutley, N. J. 
TABLE I

Effects of hemorrhage to mean arterial pressure of $60 \mathrm{~mm} \mathrm{Hg}$, of reinfusion of shed blood, and of $100 \mathrm{mU} A C T H$ on secretion of $17-O H C S^{*}$

\begin{tabular}{|c|c|c|c|}
\hline Control & Posthemorrhage & $\begin{array}{l}30 \text { minutes } \\
\text { after reinfusion }\end{array}$ & ACTH \\
\hline$\mu g / \min$ & $\mu \mathrm{g} / \min$ & $\mu g / \min$ & $\mu \mathrm{g} / \min$ \\
\hline 1.4 & 22.3 & & 19.0 \\
\hline 2.4 & 10.2 & 0.7 & 25.2 \\
\hline 1.4 & 21.6 & 2.4 & 16.4 \\
\hline $0.2 \dagger$ & 22.8 & 0.4 & 24.6 \\
\hline $3.6 \dagger$ & 29.6 & 0.6 & 30.0 \\
\hline 0.0 & 17.2 & 3.2 & 32.8 \\
\hline $1.5 \pm 0.6($ mean $\pm \mathrm{SE})$ & $20.6 \pm 3.2$ & $1.5 \pm 0.6$ & $24.7 \pm 2.7$ \\
\hline
\end{tabular}

* In this and subsequent Tables each value obtained after hemorrhage is shown with its own control, obtained before hemorrhage, and with the response of the same animal to a maximal dose of AC'TH.

$\dagger$ Nephrectomized dogs.

by simultaneous infusion of Levophed. In four additional experiments infusion of Levophed was begun after infusion of Arfonad had been maintained for 1 hour. The rate of infusion of Levophed was adjusted to return mean arterial pressure to control levels. In seven experiments, Levophed was infused alone at a rate sufficient to elevate and maintain arterial pressure at approximately $20 \mathrm{~mm} \mathrm{Hg}$ above control.

In 11 dogs (seven intact, four with vertebral arteries tied), both carotid arteries were constricted until mean arterial pressure rose $20 \mathrm{~mm} \mathrm{Hg}$. Lingual arterial pressure fell in all dogs. In 15 dogs (ten intact, five nephrectomized), the descending aorta was constricted until femoral arterial pressure fell to approximately 60 to $70 \mathrm{~mm} \mathrm{Hg}$. Because of a tendency for pressure to rise during the period of constriction, the constriction was increased by further inflation of the periaortic cuffs during most of these experiments to maintain femoral arterial pressure at this reduced level. Lingual arterial pressure rose or was stable in all of these dogs.

\section{Results}

Effect of hemorrhage with hypotension. Hemorrhage sufficient to reduce mean arterial pressure to $60 \mathrm{~mm} \mathrm{Hg}$ led to increased secretion rates of 17-OHCS in all of six experiments. The data are presented in Table $I$. The posthemorrhage values were obtained 15 minutes after hemorrhage and are not significantly different from those obtained after injection of $100 \mathrm{mU}$ ACTH. Accordingly, hemorrhage of this magnitude may be considered a maximal stimulus to secretion of 17-OHCS. The increase in secretion of 17 OHCS is highly significant [mean increase, $19.1 \pm$ $2.3 \mu \mathrm{g}$ per minute $(\mathrm{SE}) ; t=8.3 ; \mathrm{p}<0.001]$. Nephrectomy did not appear to alter the response of $17-\mathrm{OHCS}$ to hemorrhage.
Effect of hypotension without absolute hypovolemia. Infusion of Arfonad at a rate sufficient to reduce mean arterial pressure to $60 \mathrm{~mm} \mathrm{Hg}$ increased secretion rates of $17-\mathrm{OHCS}$ in 18 of 19 experiments, as shown in Table II. The response to infusion of Arfonad was prompt (15 minutes) and sustained, and the levels of secretion of 17 OHCS were maximal by the criterion noted above. The increase in secretion of $17-\mathrm{OHCS}$ is highly significant (mean increase, $13.4 \pm 1.1 \mu \mathrm{g}$ per minute; $t=11.2 ; \mathrm{p}<0.001)$. Nephrectomy did not alter the response to infusion of Arfonad.

TABLE II

Effects of infusion of Arfonad to mean arterial pressure of $60 \mathrm{~mm} \mathrm{Hg}$ and of $100 \mathrm{mU}$ ACTH on secretion of 17-OHCS

\begin{tabular}{ccc}
\hline Control & Postinfusion & ACTH \\
\hline$\mu g /$ min & $\mu g /$ min & $\mu g /$ min \\
$1.0^{*}$ & 11.6 & 15.0 \\
0.1 & 14.7 & 14.8 \\
$5.2^{*}$ & 14.8 & 14.6 \\
3.6 & 14.2 & 20.6 \\
3.2 & 14.6 & 9.4 \\
0.6 & 20.2 & 19.1 \\
$1.4^{*}$ & 16.8 & 21.4 \\
$0.0^{*}$ & 20.8 & 21.4 \\
7.1 & 20.0 & 20.0 \\
0.5 & 13.6 & 14.2 \\
0.0 & 17.0 & 17.4 \\
0.0 & 14.8 & 18.0 \\
$2.9^{*}$ & 10.6 & 11.6 \\
$0.0^{*}$ & 10.1 & 11.6 \\
1.6 & 13.1 & 13.4 \\
0.8 & 3.6 & 19.2 \\
0.9 & 21.7 & 20.7 \\
0.4 & 14.4 & 15.6 \\
0.4 & 18.2 & 22.0 \\
$1.6 \pm 0.3$ & $15.0 \pm 0.9$ & $17.3 \pm 0.7$ \\
\hline
\end{tabular}

* Nephrectomized dogs. 
TABLE III

Effects of simultaneous infusion of Arfonad* and l-norepinephrine ${ }^{\text {and }} 100 \mathrm{mU} A C T H$ on secretion of 17-OHCS

\begin{tabular}{ccc}
\hline Control & Postinfusion & ACTH \\
\hline$\mu g / \min$ & $\mu g / \min$ & $\mu g / \min$ \\
$0.4 \ddagger$ & 0.4 & 15.0 \\
$2.4 \ddagger$ & 1.0 & 14.6 \\
6.8 & 5.4 & 20.6 \\
0.6 & 2.0 & 9.4 \\
4.4 & 4.6 & 9.4 \\
$2.9 \pm 1.2$ & $2.7 \pm 0.9$ & $13.8 \pm 2.2$
\end{tabular}

* At a rate equivalent to that used in the experiments of Table II.

$\dagger$ At a rate sufficient to prevent a fall of arterial pressure. $\ddagger$ Nephrectomized dogs.

Effect of infusion of Arfonad without hypotension. Infusion of Arfonad at approximately the same rate as that used above, when accompanied by simultaneous infusion of Levophed at a rate sufficient to prevent hypotension, did not change secretion rates of $17-\mathrm{OHCS}$ in five experiments (Table III). All animals were responsive to ACTH and to infusion of Arfonad with hypotension. There was no significant change in secretion of 17-OHCS (mean increase, $-0.2 \pm 0.5$ $\mu \mathrm{g}$ per minute; $t=0.4 ; \mathrm{p}>0.5)$. The difference between the means of this group and the group infused with Arfonad alone is highly significant $(t=10.7, \mathrm{p}<0.001)$.

Effect of infusion of Levophed in normotensive animals. Infusion of Levophed at a rate sufficient to increase mean arterial pressure $20 \mathrm{~mm} \mathrm{Hg}$ had no consistent effect on secretion of 17-OHCS in seven experiments. The data are presented in Table IV. All animals were normally responsive to

TABLE IV

Effects of infusion of l-norepinephrine* and of $100 \mathrm{mU}$ $A C T H$ on secretion of 17-OHCS

\begin{tabular}{ccc}
\hline Control & Postinfusion & ACTH \\
\hline$\mu g / \min$ & $\mu g / \min$ & $\mu g / \min$ \\
1.6 & 0.8 & 25.2 \\
1.2 & 0.5 & 22.0 \\
1.4 & 2.6 & 20.0 \\
1.6 & 1.5 & 10.3 \\
2.2 & 0.9 & 15.2 \\
0.0 & 0.5 & 13.4 \\
1.2 & 0.0 & 13.4 \\
$1.3 \pm 0.3$ & $1.0 \pm 0.3$ & $17.1 \pm 2.1$
\end{tabular}

* At a rate sufficient to elevate mean arterial pressure $20 \mathrm{~mm} \mathrm{Hg}$.
ACTH. There is no significant change in secretion rate of $17-\mathrm{OHCS}$ in response to infusion with Levophed (mean increase, $-0.34 \pm 0.34 \mu \mathrm{g}$ per minute ; $t=1.00 ; \mathrm{p}>0.2$ ) associated with elevation of arterial pressure to supranormal levels.

Effect of infusion of Levophed in hypotensive animals. Infusion of Levophed at a rate sufficient to return the mean arterial pressure of dogs being infused concurrently with Arfonad from $60 \mathrm{~mm}$ $\mathrm{Hg}$ to control levels decreased secretion rates of $17-\mathrm{OHCS}$ in each of four experiments (Table V). The decrease in secretion of $17-\mathrm{OHCS}$ was prompt, appearing within 15 minutes after the return of arterial pressure to control. Despite the small number of animals, the decrease in secretion of $17-\mathrm{OHCS}$ is significant (mean decrease, $-9.28 \pm 1.97 \mu \mathrm{g}$ per minute; $t=4.72 ; \mathrm{p}<$ $0.025)$.

TABLE $V$

Effects of infusion of l-norepinephrine* and of $100 \mathrm{mU}$ $A C T H$ on secretion of 17-OHCS

\begin{tabular}{ccc}
\hline \hline Control $\dagger$ & Postinfusion & ACTH \\
\hline$\mu g / \min$ & $\mu g / \min$ & $\mu g / \min$ \\
11.5 & 1.2 & 14.2 \\
17.8 & 3.6 & 17.4 \\
10.3 & 1.6 & 20.0 \\
5.9 & 2.0 & 10.8 \\
$11.4 \pm 3.0$ & $2.1 \pm 0.6$ & $15.6 \pm 2.3$ \\
\hline
\end{tabular}

* At a rate sufficient to return mean arterial pressure from $60 \mathrm{~mm} \mathrm{Hg}$ to control levels in dogs made hypotensive by prior infusion of Arfonad.

Effect of hemorrhage zrithout hypotension. Hemorrhage of 400 to $500 \mathrm{ml}$, an amount usually sufficient to decrease mean arterial pressure to $60 \mathrm{~mm}$, but with hypotension prevented by simultaneous infusion of Levophed, increased secretion of 17-OHCS in all of eight experiments, as shown in Table VI. Five of the dogs had undergone hemorrhage with hypotension previously, and the hemorrhage during infusion of Levophed involved the same volume. The response to hemorrhage was prompt, and the levels of secretion of 17OHCS after hemorrhage were maximal. The increase in secretion of 17-OHCS with hemorrhage but without hypotension is highly significant (mean increase, $16.2 \pm 2.2 \mu \mathrm{g}$ per minute; $t=$ $7.24 ; \mathrm{p}<0.001)$. Nephrectomy did not alter the response to hemorrhage without hypotension. There is no significant difference between the in- 
TABLE VI

Effects of simultaneous hemorrhage* and infusion of l-norepinephrine, $\dagger$ of reinfusion of shed blood, and of $100 \mathrm{mU}$ $A C T H$ on secretion of 17-OHCS

\begin{tabular}{cccc}
\hline \hline Control & Posthemorrhage & $\begin{array}{c}\text { 30 min- } \\
\text { utes after } \\
\text { reinfusion }\end{array}$ & ACTH \\
\hline$\mu g / \min$ & $\mu g / \min$ & $\mu \mathrm{g} / \mathrm{min}$ & $\mu \mathrm{g} / \mathrm{min}$ \\
1.7 & 17.3 & & 164. \\
5.2 & 14.4 & 0.8 & 25.2 \\
1.8 & 9.2 & & 32.8 \\
3.2 & 26.4 & & 20.6 \\
$0.4 \ddagger$ & 16.4 & & 14.8 \\
$3.0 \ddagger$ & 13.4 & 4.2 & 14.0 \\
$1.0 \ddagger$ & 23.0 & & 24.6 \\
$9.2 \ddagger$ & 25.9 & & 30.0 \\
& & & $22.3 \pm 2.4$
\end{tabular}

* Of a volume comparable to that in the experiments of Table I.

$\dagger$ At a rate sufficient to prevent a fall of arterial pressure. $\ddagger$ Nephrectomized dogs.

creases in secretion of $17-\mathrm{OHCS}$ in response to hemorrhage with or without hypotension ( $t=$ $0.9, \mathrm{p}>0.2$ ).

Effect of rapid reinfusion of shed blood. Rapid transfusion (blood infused within 5 minutes) in hemorrhaged dogs led to return of secretion of 17-OHCS to control levels in seven experiments (five in hypotensive dogs, two in dogs kept normotensive with Levophed). The data are presented in Tables I and VI. The decrease in secretion of 17-OHCS was apparent in four of the animals at 15 minutes and in all at 30 minutes. Prior hypotension was not a prerequisite for a response of secretion of $17-\mathrm{OHCS}$ to rapid transfusion. Nephrectomy did not alter this response.

TABLE VII

Effects of bilateral constriction of the common carotid arteries low in the neck and of $100 \mathrm{mU} A C T H$ on secretion of 17-OHCS

\begin{tabular}{cccc}
\hline \hline & $\begin{array}{c}\text { Constric- } \\
\text { tion 10 } \\
\text { minutes }\end{array}$ & $\begin{array}{c}\text { Constric- } \\
\text { tion 30 } \\
\text { minutes }\end{array}$ & ACTH \\
\hline$\mu g / \min$ & $\mu g / \min$ & $\mu g / \min$ & $\mu g / \min$ \\
$2.0^{*}$ & 0.0 & 0.3 & 12.2 \\
1.3 & 1.5 & 0.1 & 12.8 \\
0.0 & 0.6 & 0.2 & 10.6 \\
4.8 & 3.9 & 3.9 & 20.6 \\
$0.0^{*}$ & 0.0 & 0.0 & 20.8 \\
2.7 & 1.7 & 5.3 & 24.6 \\
$0.8^{*}$ & 0.6 & 0.4 & 20.8 \\
$7.9^{*}$ & 0.3 & 0.5 & 13.4 \\
2.0 & 0.1 & 0.8 & 12.6 \\
0.9 & 0.3 & 1.8 & 23.2 \\
0.2 & 1.0 & $1.2 \pm 0.5$ & $17.3 \pm 1.3$ \\
$2.1 \pm 0.7$ & $0.9 \pm 0.4$ & & \\
\hline
\end{tabular}

* Vertebral arteries tied.
The decrease in secretion of $17-\mathrm{OHCS}$ is highly significant (mean decrease, $16.7 \pm 2.7 \mu \mathrm{g}$ per minute $t=6.1 ; \mathrm{p}<0.001)$.

Effect of bilateral carotid constriction. Bilateral constriction of the common carotid arteries low in the neck sufficient to increase mean femoral arterial pressure $20 \mathrm{~mm} \mathrm{Hg}$, and associated with lingual arterial hypotension $(60 \mathrm{~mm} \mathrm{Hg})$, had no consistent effect on secretion of $17-\mathrm{OHCS}$ in 11 experiments (Table VII). All animals were responsive to ACTH. There is no significant increase in secretion of $17-\mathrm{OHCS}$ at 10 (mean increase, $-0.8 \pm 0.9 \mu \mathrm{g}$ per minute; $t=0.88$; $\mathrm{p}>0.2$ ) or 30 (mean increase, $-1.1 \pm 0.7 \mu \mathrm{g}$

TABLE VIII

Effects of constriction of the descending thoracic aorta and of $100 \mathrm{mU} A C T H$ on secretion of 17-OHCS in intact and in nephrectomized dogs

\begin{tabular}{|c|c|c|c|}
\hline Control & $\begin{array}{l}\text { Constric- } \\
\text { tion } 10 \\
\text { minutes }\end{array}$ & $\begin{array}{l}\text { Constric- } \\
\text { tion } 30 \\
\text { minutes }\end{array}$ & ACTH \\
\hline$\mu g / \min$ & $\mu g / \min$ & $\mu g / \min$ & $\mu g / \min$ \\
\hline $\begin{array}{l}4.9 \\
4.8 \\
4.2 \\
0.8 \\
4.4 \\
0.9 \\
2.7 \\
1.8 \\
2.6 \\
2.0\end{array}$ & $\begin{array}{l}4.1 \\
6.6 \\
2.3 \\
2.1 \\
2.8 \\
1.5 \\
0.4\end{array}$ & $\begin{array}{r}5.5 \\
10.7 \\
1.7 \\
5.4 \\
7.2 \\
10.8 \\
3.0 \\
9.9 \\
4.2 \\
6.0\end{array}$ & $\begin{array}{l}14.4 \\
19.2 \\
21.6 \\
17.2 \\
20.8 \\
20.7 \\
24.6 \\
12.4 \\
10.2 \\
12.3\end{array}$ \\
\hline $\begin{array}{l}2.4^{*} \\
0.2^{*} \\
0.2^{*} \\
1.1^{*} \\
0.8^{*}\end{array}$ & & $\begin{array}{l}2.6 \\
0.0 \\
0.6 \\
0.5 \\
1.1\end{array}$ & $\begin{array}{l}15.4 \\
11.0 \\
14.6 \\
14.5 \\
14.5\end{array}$ \\
\hline $\begin{array}{l}2.9 \pm 0.4 \dagger \\
0.9 \pm 0.4^{*}\end{array}$ & $2.8 \pm 0.9 \dagger$ & $\begin{array}{l}6.4 \pm 0.9 \dagger \\
0.9 \pm 0.5^{*}\end{array}$ & $\begin{array}{l}17.3 \pm 1.4 \dagger \\
14.0 \pm 0.9^{*}\end{array}$ \\
\hline
\end{tabular}

* Nephrectomized dogs.

† Intact dogs.

per minute; $t=1.57 ; \mathrm{p}>0.1)$ minutes after constriction. Prior ligation of both vertebral arteries, which may have predisposed to cerebral hypotension after carotid constriction, had no effect on the absent response to carotid constriction.

Effect of aortic constriction. Constriction of the descending aorta sufficient to decrease mean femoral arterial pressure to 60 to $70 \mathrm{~mm} \mathrm{Hg}$ had no consistent effect on secretion of 17-OHCS at 10 minutes. However, an increase in secretion of 17-OHCS became apparent at 30 minutes in intact dogs, but not in nephrectomized dogs. The data are presented in Table VIII. All animals were responsive to ACTH. There is no significant change in secretion of $17-\mathrm{OHCS}$ in intact dogs at 
10 minutes (mean increase, $-0.4 \pm 0.5 \mu \mathrm{g}$ per minute; $t=0.8 ; \mathrm{p}>0.4)$. The increase in secretion of $17-\mathrm{OHCS}$ in seven intact dogs at $30 \mathrm{~min}$ utes is small but significant (mean increase, $3.5 \pm$ $1.2 \mu \mathrm{g}$ per minute; $t=2.92 ; \mathrm{p}<0.025)$. However, the final secretion rate is significantly less than the mean response to ACTH $(t=6.53$, p $<$ $0.001)$. There is no significant increase in secretion of $17-\mathrm{OHCS}$ in nephrectomized dogs at 30 minutes (mean increase, $0.02 \pm 0.18 \mu \mathrm{g}$ per minute; $t=0.11 ; \mathrm{p}>0.5)$. The difference in responses of secretion of $17-\mathrm{OHCS}$ in intact and in nephrectomized dogs is significant $(t=2.75$, $\mathrm{p}<0.025)$. Thus, aortic constriction leads to a small late increase in secretion of $17-\mathrm{OHCS}$ that is prevented by prior nephrectomy.

\section{Discussion}

Hemorrhage accompanied by moderate arterial hypotension has been shown in these studies to be an effective, consistent, and maximal stimulus to secretion of 17-OHCS (Table I). The effect is present within 15 minutes. Although similar experiments have been reported by numerous workers (1-6), no previous reports in which secretion rates of $17-\mathrm{OHCS}$ were measured describe a consistent response to hemorrhage, and some groups have described unchanged $(4,6,7)$ or decreased (6) secretion of 17-OHCS after hemorrhage. There are two probable explanations for these discrepancies. First, many animals reported by the workers cited above have been subjected to more severe hypotension than the animals in the present experiments and accordingly demonstrated severely decreased adrenal blood flow. When such decreases are large, they may lead to a low calculated secretion rate despite increased concentration of steroid in adrenal venous blood (4). Second, all previous studies have utilized at least some animals prepared acutely. As noted previously $(2,7)$, such animals secrete $17-\mathrm{OHCS}$ at high rates, so that the effect of a superimposed stimulus may be obscured. In our studies, all animals were prepared on the day before the experiment, and animals with high control secretion rates were excluded, as noted above. The injection of a test dose of ACTH in these studies allowed us to exclude as well an occasional dog that did not re- spond to ACTH. These measures resulted in a more nearly homogeneous group of dogs than others have used.

Hypotension produced by infusion of Arfonad is also a consistent and maximal stimulus to secretion of 17-OHCS, as shown in these studies (Table II). The effect is present within $15 \mathrm{~min}-$ utes. That this stimulation resulted from the hypotension produced by the drug rather than from an independent effect of the drug is shown by the results in Table III, in which hypotension was prevented by simultaneous infusion of Levophed and the animals failed to respond. In addition, increased secretion of 17-OHCS has been observed following infusion of hexamethonium (10).

Since hypotension is an effective stimulus to secretion of 17-OHCS, we considered the possibility that the response to hemorrhage might be mediated through hypotension. However, as shown in Table VI, hemorrhage remained an effective and maximal stimulus even in the absence of hypotension, prevented by simultaneous infusion of Levophed. Accordingly, hypovolemia can apparently stimulate the adrenal through a mechanism not involving arterial hypotension. This conclusion was suggested also by Atkins and Marotta (11); in measuring peripheral blood concentrations of $17-\mathrm{OHCS}$, the response to hemorrhage appeared to these workers out of proportion to the hypotension. The mechanisms involved in stimulating secretion of 17-OHCS by hypovolemia alone are unknown but are currently under study.

Rapid reinfusion of blood shed during hemorrhage leads to return of secretion rates of 17 OHCS to normal as shown in Tables I and VI. The return was not present consistently until 30 minutes after transfusion, although it appeared earlier in some animals. The reinfusion was associated with a rise in mean arterial pressure in those dogs in which the pressure had been allowed to fall. However, the pressure change was not necessary for this response, which occurred in both dogs shown in Table VI. In these animals, Levophed was stopped as the blood was infused, an attempt being made to keep the pressure constant. Although restoration of volume thus leads to decreased secretion of 17-OHCS in the absence of increased arterial pressure, an effect 
of increased pressure is by no means excluded. Other data in these studies suggest such an effect. Levophed does not change secretion rates of 17 OHCS in resting animals, as shown in Table IV. However, when hypotension has been produced with Arfonad, infusion of Levophed at a rate sufficient to return mean arterial pressure to control levels leads to reduced secretion of $17-\mathrm{OHCS}$ within 15 minutes, as shown in Table V.

Attempting to delineate the mechanisms involved in the response of secretion of $17-\mathrm{OHCS}$ to hypotension, we performed experiments involving local hypotension. Bilateral constriction of the common carotid arteries had no effect on secretion of 17-OHCS, despite the presence of intracarotid hypotension. The addition of vertebral arterial ligation did not alter this absence of response. Accordingly, it seems likely that carotid or intracranial receptors do not play a principal role in the mediation of the response to hypotension. A secondary role for such receptors seems likely, however, on the basis of other experiments (12) in which it has been shown that carotid constriction is an effective stimulus to secretion of $17-\mathrm{OHCS}$ in $\operatorname{dogs}$ vagotomized previously. Carotid constriction has been shown to stimulate secretion of aldosterone (8), and it has been suggested that such stimulation is probably the result of increased release of $\mathrm{ACTH}(13,14)$. The present experiments make this explanation seem unlikely, as do other experiments in which carotid constriction led to increased secretion of aldosterone without inducing changes in the secretion of cortisol (15).

Constriction of the descending aorta, with distal arterial hypotension, had no effect on secretion rates of $17-\mathrm{OHCS}$ at 15 minutes, a time when secretion of $17-\mathrm{OHCS}$ was maximal after hemorrhage or pharmacologic hypotension. Accordingly, it seems likely that the principal receptors mediating the response to hypotension do not lie beyond the aortic arch. However, a small but significant increase in secretion of $17-\mathrm{OHCS}$ was observed after 30 minutes. This response was abolished by prior nephrectomy (Table VIII). Since arterial hypotension stimulates renin release and thus angiotensin formation (16) and since angiotensin stimulates secretion of cortisol (17), this effect may be mediated through the renin-angiotensin system. However, nephrectomy was without demonstrable effect on the responses of secretion of $17-\mathrm{OHCS}$ to hemorrhage with or without hypotension, to hypotension without hemorrhage, to transfusion, or to restoration of pressure. Thus, it seems likely that the physiologic role of this system in the control of secretion of $17-\mathrm{OHCS}$ is not critical.

Constriction of the thoracic inferior vena cava traps blood behind the constriction and produces hypotension in the heart and the arterial tree $(18,19)$. Caval constriction is also a maximal stimulus to secretion of $17-\mathrm{OHCS}$ (19). Since this effect is not reproduced by constriction of the carotid arteries or of the descending aorta, a principal receptor mediating the response of secretion of $17-\mathrm{OHCS}$ to hypotension may possibly lie in or near the heart or aortic arch. Afferent nerves arising from this region travel in the vagus nerves. Accordingly, it is of interest that vagotomy has been shown to be a maximal stimulus to secretion of $17-\mathrm{OHCS}$ (12). The mechanisms involved are not well defined and are currently under study.

\section{Summary}

Secretion rates of 17-hydroxycorticosteroids were measured in dogs with chronic adrenal venous cannulas before and after various hemodynamic manipulations. Both hemorrhage and hypotension produced by ganglionic blockage consistently stimulated secretion of corticosteroids. Prevention of hypotension by concomitant administration of norepinephrine prevented the response to ganglionic blockade but not that to hemorrhage. Reinfusion of shed blood in hemorrhaged animals and restoration of blood pressure in animals with blockade led to rapid return of secretion of corticosteroids to control levels. Bilateral carotid constriction did not affect secretion of corticosteroids, but the response was small and delayed. This response was prevented by prior bilateral nephrectomy, but nephrectomy did not alter the responses to hemorrhage or to hypotension. We conclude that hypotension alone is an effective stimulus to secretion of corticosteroids, but hypovolemia stimulates secretion of corticosteroids even in the absence of hypotension. The mechanisms mediating adrenal activation in response to these stimuli have not been defined by the present studies. 


\section{References}

1. Sayers, G., M. A. Sayers, T. Y. Liang, and C. N. H. Long. The cholesterol and ascorbic acid content of the adrenal, liver, brain and plasma following hemorrhage. Endocrinology 1945, 37, 96.

2. Hume, D. M., and D. H. Nelson. Adrenal cortical function in surgical shock. Surg. Forum 1955, 5, 568.

3. Farrell, G. L., R. A. Rosnagle, and E. W. Rauschkolb. Increased aldosterone secretion in response to blood loss. Circulat. Res. 1956, 4, 606.

4. Walker, W. F., W. C. Shoemaker, A. J. Kaalstad, and F. D. Moore. Influence of blood volume restoration and tissue trauma on corticosteroid secretion in dogs. Amer. J. Physiol. 1959, 197, 781.

5. Mulrow, P. J., and W. F. Ganong. The effect of hemorrhage upon aldosterone secretion in normal and hypophysectomized dogs. J. clin. Invest. 1961, 40, 579.

6. Frank, H. A., E. D. Frank, H. Korman, I. A. Macchi, and O. Hechter. Corticosteroid output and adrenal blood flow during hemorrhagic shock in the dog. Amer. J. Physiol. 1955, 182, 24.

7. Ganong, W. F., W. F. Bernhard, and J. D. McMurrey. The effect of hypothermia on the output of 17-hydroxycorticosteroids from the adrenal vein in the dog. Surgery 1955, 38, 506.

8. Bartter, F. C., I. H. Mills, and D. S. Gann. Increase in aldosterone secretion by carotid artery constriction in the dog and its prevention by thyrocarotid arterial junction denervation. J. clin. Invest. 1960, 39, 1330.

9. Peterson, R. E., A. Karrer, and S. L. Guerra. Evaluation of Silber-Porter procedure for determination of plasma hydrocortisone. Analyt. Chem. 1957, 29, 144.
10. Gann, Donald S., and Richard H. Egdahl. Unpublished observations.

11. Atkins, G., and S. F. Marotta. Relationship of altered vascular volumes to plasma 17-hydroxycorticosteroids in dogs. Proc. Soc. exp. Biol. (N. Y.) 1963, 113, 461.

12. Gann, D. S., K. L. Gould, J. E. Morley, and J. V. Mumma. Effects of vagotomy and of carotid constriction on corticosteroid secretion in the dog. Proc. Soc. exp. Biol. (N. Y.) 1964, 115, 944.

13. Biglieri, E. G., and W. F. Ganong. Effect of hypophysectomy on adrenocortical response to bilateral carotid constriction. Proc. Soc. exp. Biol. (N. Y.) 1961, 106, 806.

14. Carpenter, C. C. J., J. O. Davis, and C. R. Ayers. Concerning the role of arterial baroreceptors in the control of aldosterone secretion. J. clin. Invest. 1961, 40, 1160.

15. Gann, D. S., and R. H. Travis. Mechanisms of hemodynamic control of secretion of aldosterone in the dog. Amer. J. Physiol. 1964, in press.

16. Skinner, S. L., J. W. McCubbin, and I. H. Page. Renal baroceptor control of renin secretion. Science 1963, 141, 814.

17. Slater, J. D. H., B. H. Barbour, H. H. Henderson, A. G. T. Casper, and F. C. Bartter. Influence of the pituitary and the renin-angiotensin system on the secretion of aldosterone, cortisol and corticosterone. J. clin. Invest. 1963, 42, 1504.

18. Gann, D. S., I. H. Mills, and F. C. Bartter. On the hemodynamic parameter mediating increase in aldosterone secretion in the dog. Fed. Proc. 1960, 19, 605.

19. Egdahl, R. H. Corticosteroid secretion following caval constriction in dogs with isolated pituitaries. Endocrinology 1961, 68, 226. 